S

\title{
Hanford Year 2000 Business Continuity Plan
}

November, 1999

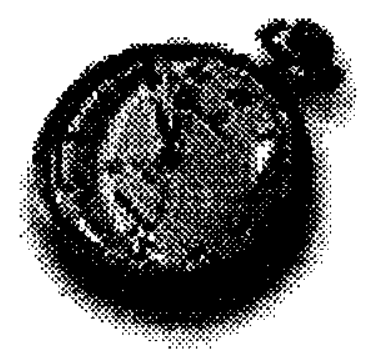

Approved by:

S.V. Forney, Y2K Project Manager

Date 


\section{INFORMATION CLEARANCE FORM}

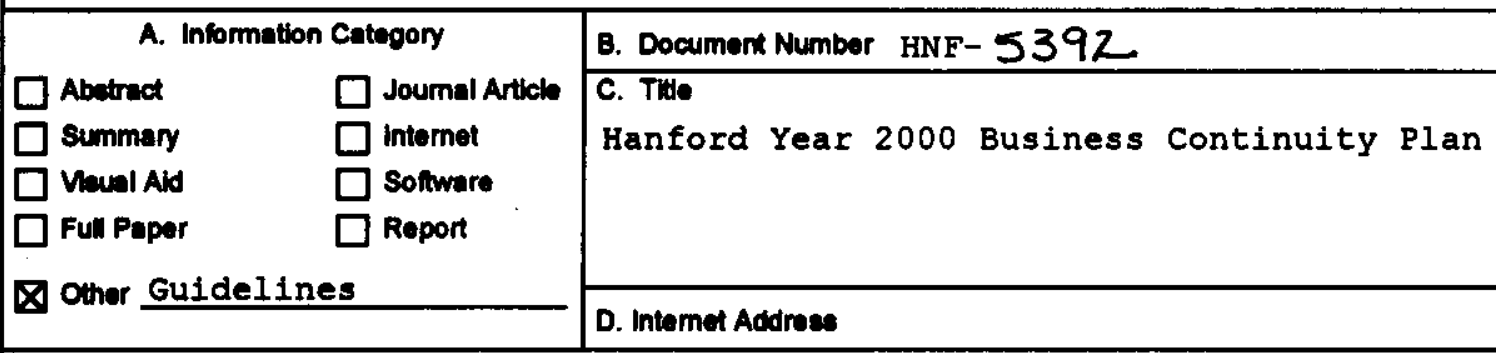

E. Required Information

1. Is gpoument potentially claseified? ONo OYes (MANDATORY) tr.

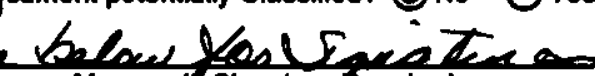
Manages Signaturetrequired

If Yes ADC Signature Required

Ono Oree claseditiod

2. Intemal Roview Required?

if Yos, Document Signatures Below

ONo OYos

Couneal

Program

3. Rowrences in the Information are Applied Technology ONo OYes Export Controlled information Ono Ores

4. Does Information Contain the Following: (MANDATORY)

a. Now or Novel (Patentablo) subject Matter? ONo OYes If "Yos", Dieclosure No.:

b. Information Rocoived in Confidenco, Such as Proprbtary and/or Inventiona? ONo OYes I'Yes", AFlx Appropriate Legends/Notices.

c. copyrlohte? ONo OYes I"Yos", Attach Pormiselon.

d. Trademarke? ONo OYes H'Yes', kentily in Document.

5. Is Information requiring submisaion to OSTI? $O$ No $O$ Yos

If Yos UCand $B \& R-$

6. Reloace Level? O Public $\mathrm{O}$ Limited

7. Charge code $6 / 2 / F D Q 19 / \quad 0 / 9$

F. Complete. for a Journal Article

1. Twie of Joumal

G. Complete for a Presentation

1. THio for Conforence or Meeting

2. Group Sponsoring

3. Date of Conference

5. will information be Publiahed in Proceedings? ONo OYes

H. Author/Requector

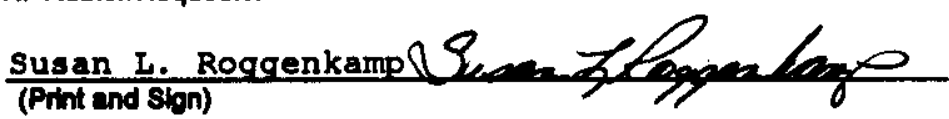
I. Roviowere Yes Print

4. City/State

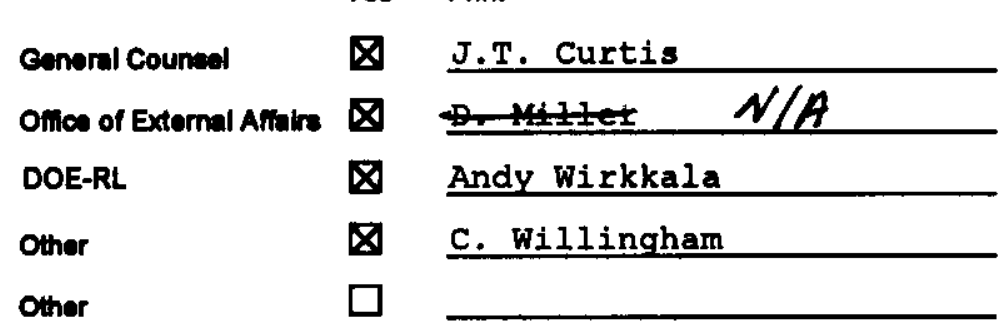

6. Will Material be Handed Out? No

Responsible Manager

vic Forney (Print and Sign) Signature

Public Y/N (If N, complete J) Leeperezentignam $Y / N$

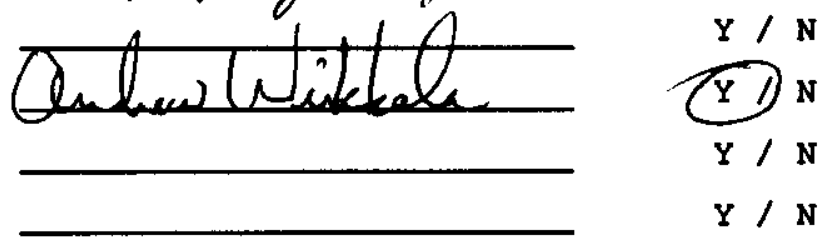

J. If Information Includes Seneltive Information and is not to be released to the Public indicate category below.

$\square$ Applied Technology $\square$ Protected CRADA

$\square$ PereonaUPitvate $\square$ Export Controlled

$\square$ Propriotary $\square$ Procurement-Senaltive

$\square$ Businese-sonattive $\square$ Patentable

$\square$ Predeciaional $\square$ other (Specily)

$\square$ UCNI

K. If Addkional Comments, Please Attach Separate Sheot

anse $/ 82$

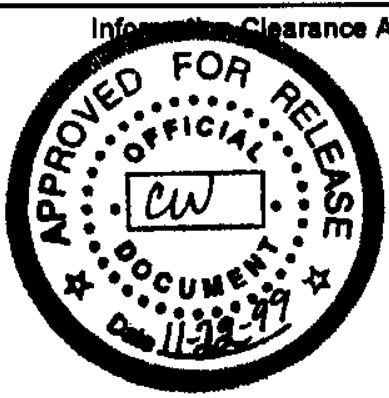


$21^{3} s^{99}$

\begin{tabular}{|c|c|}
\hline \multicolumn{2}{|c|}{ A. Information Category } \\
\hline $\begin{array}{l}\square \text { Abstract } \\
\square \text { summary } \\
\square \text { Vosul Aid } \\
\square \text { Full Papar }\end{array}$ & $\begin{array}{l}\square \text { Joumal Artide } \\
\square \text { Intemet } \\
\square \text { sofmure } \\
\square \text { Report }\end{array}$ \\
\hline$\exists$ Other Gu & \\
\hline
\end{tabular}

\section{INFORMATION CLEARANCE FORM}

B. Document Number ENF- 5392

C. Title

Honford Year 2000 Business Continuity Plan

\section{Internet Addreses}

E Required Information

1. Is dgament potentally Classitied? ONo Ores MaNDaToRn

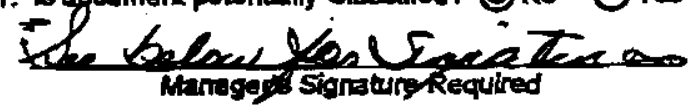

If Yes ADC Signabure Requirod

Ono Ores clascified

2 Intemal Roview Regulred? if Yes, Doement Signatures Bolow

ONo OYes

Couneel

Program

3. References in the information are Appled Technology ONo OYes Expoit Controlled Intormation Ono Ores

4. Does Ifformation Contan the Following: MANDATORY

a. New or Novel (Pabnablo) subject Matmen ONo OYes "Yos", Dbedosure No:-

b. Irformation Recatved in Comidenco. Such as Propriatery and/or Imvartions? ONo OYes ares", Arix Appropitat LagenderNoticen-

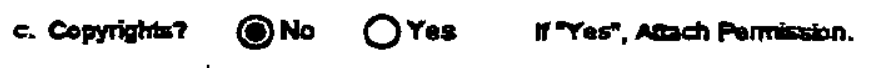

d. Traderrarks? ONo OYes WYas, Bentity in Docamont

5. Is Infomation requiring aubmission to OSTn? $O$ no $O$ Yes

IfYes $\sigma C$ - _ a $B G R$ -

6. Ralaca Lever? $O$ Public $O$ Limited

7. Charge code $\angle / L / F D$ DS $19 /$ O/9

F. Complete.for a Joumal Artiste

1. Thite of Journal

G. Complete for a Presentation

1. Twe for Conference or Meeting

2. Crowp sponsoring

3. Date of Conference

5. Woll information be Publiched in Proceedings? ONo OYes

4. City/Suta

H. Authorikequestor Susan I. Roggonkamp 9 (P)

I. Revismers Yes Print Signiture

6. Wm Matartal be Handed Out? Rexpondible Manager
vic Forney
(Print and Sign)

$\begin{array}{llll}\text { Ceneral Couneal } & \Delta \text { J.T. Curtis } \\ \text { Ofines of External Affals } & N / A\end{array}$

Q. Purtis

Public YaN (if $N$, complete J)

Ofice of External Afialis

Q Andr Wirkkala

(Y)/ $\mathrm{N}$

DOE-RL

8 C. Willingham

$\mathbf{Y} / \mathrm{N}$

other

[

$\mathbf{Y} / \mathbf{N}$

$\mathbf{Y} / \mathbf{N}$

$\mathbf{Y} / \mathbf{N}$

J. If untomation Includes sersitive information and is not to be releaged to the Public indicate category balow.
$\square$ Applied Technology
$\square$ Personuprate
$\square$ Proprietary
$\square$ Bucinessesenalive
$\square$ Protect CRADA
$\square$ Export Controlled
$\square$ Procarement-Sensitive
$\square$ Predecitorn?
D Patentable
$\square$ uCNI
$\square$ Other (Specify) 


\section{RELEASE AUTHORIZATION}

Document Number:

Document Title:
HNF-5392, Rev. 0

\section{This document, reviewed in accordance with DOE Order 241.1, "Sclentific and Technical Information Management," and DOE G 241.1-1, "Guide to the Management of Scientific and Technical Information," does not contain classifled or sensitive unclassified information and is:}

\section{APPROVED FOR PUBLIC RELEASE}

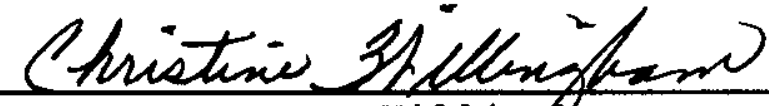 \\ C. Willingham}

Lockheed Martin Services, Inc.

Document Control / Information Clearance

Rovlewed lor Applied Technology, Businece Senclive, Checilied, Copyrighted, Export Controlled, Patent, PersonaVPrivate, Proprietary, Protected CRADA, Tradomark, Unciaselined Controilid Nicter intormation.

LECAL DISCLAMER. This report wae propared as an account of work sponeored by an agency of the Uniked States Covernment. Nether the United states covemmont nor any agency thereof, not any of that employees, nor any of their

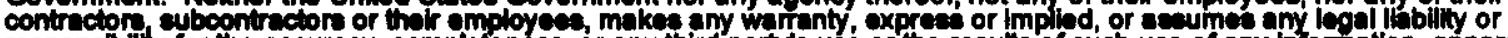

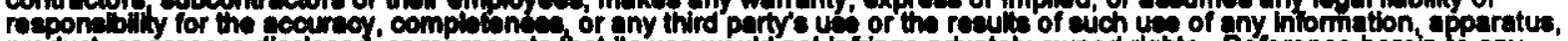

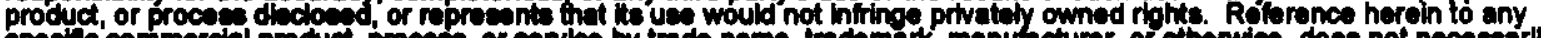

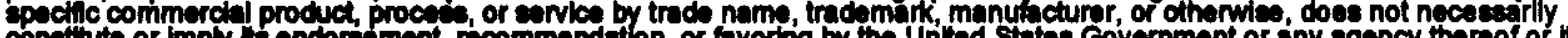

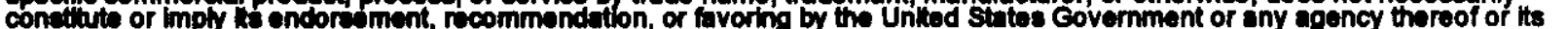
contractors or subcontructors. The viewe end opinione of authore expreseced hereln do not necectearily atate or retied those of the United Sthtes Government or eny egency thereof. This report has beon roproduced from the beat avallable copy. Printed in the United States of America. 


\section{Table of Contents}

1.0 OVERVIEW

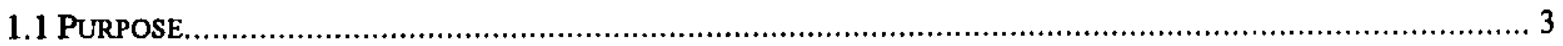

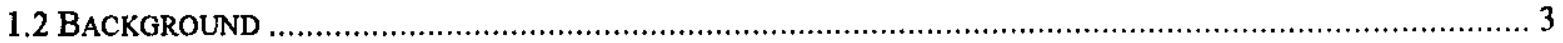

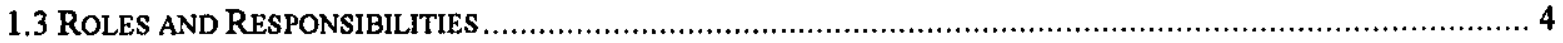

2.0 HANFORD'S BUSINESS CONTINUITY PLANNING PROCESS....................................................... 4

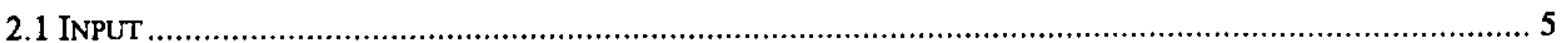

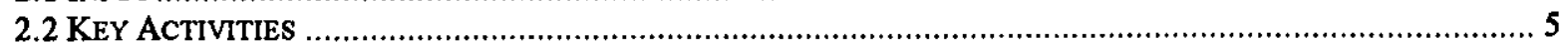

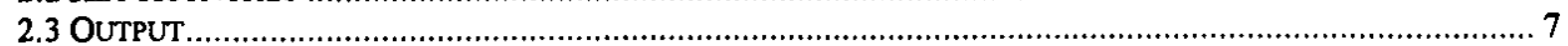

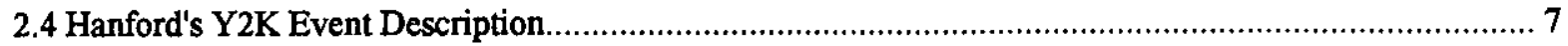

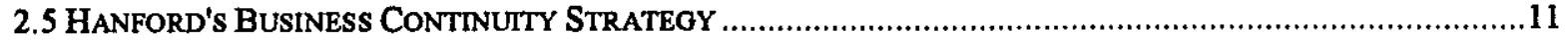

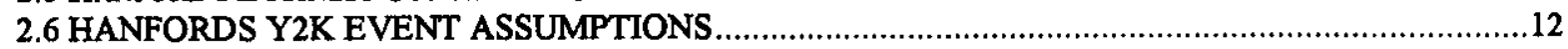

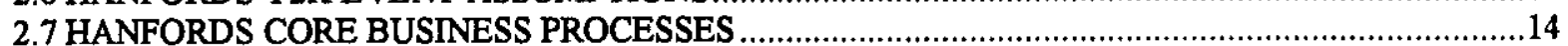

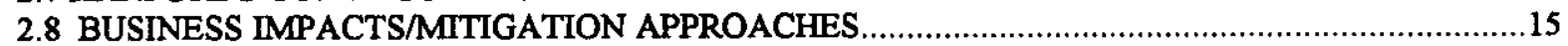

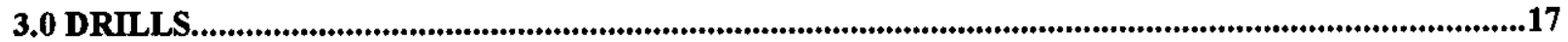

4.0 SCHEDULES/MILESTONES AND COST ESTIMATES................................................................19

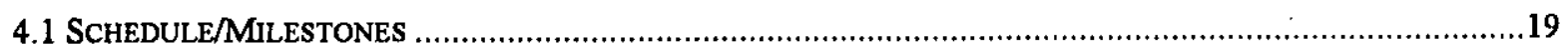

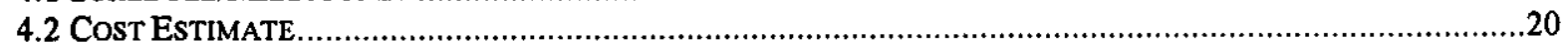

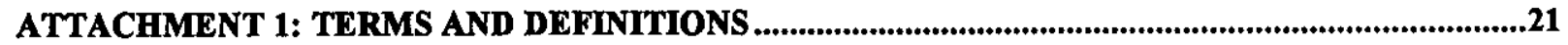

ATTACHMENT 2: Y2K CONTINGENCY PLAN GUIDELINES ..........................................................23

ATTACHMENT 3: ASSURANCE OF MISSION-CRITICAL SYSTEM CONTINGENCY PLAN

COMPLETION 


\section{Hanford Year 2000 Business Continuity Plan}

\subsection{OVERVIEW}

\subsection{PURPose}

The goal of Department of Energy Richland Operations (DOE-RL) Year 2000 (Y2K) effort is to ensure that the Hanford site successfully continues its mission as we approach and enter the $21^{\text {st }}$ century. The Y2K Business Continuity Planning process provides a structured approach to identify Y2K risks to the site and to mitigate these risks through Y2K Contingency Planning, "Zero-Day" Transition Planning and Emergency Preparedness.

This document defines the responsibilities, processes and plans for Hanford's Y2K Business Continuity. It identifies proposed business continuity drills, tentative schedule and milestones.

\subsection{BACKGROUND}

Few topics are creating as much interest, or are as widely misunderstood as the approaching Y2K date change problem. There are a number of myths, fallacies and irresponsible assertions circulating about the impact of Y2K failures. DOE-RL's objective is to assess and respond appropriately to the possibility of Y2K failures of both internal systems and external services. In this regard, it is recognized that the Y2K event is different from other natural and manmade events that DOE-RL has addressed. This difference is best described in terms of complexity, humanity and simultaneity.

Complexity - The Y2K date change problem exists in technologically complex systems that influence Hanford operations. Y2K events could emulate from a multitude of sources including internal computers, embedded systems and infrastructure equipment and external services including electrical power and telephones, etc.

Humanity - Y2K is not just a technology issue; people are involved. As such, it is expected that human errors will occur in fixing Y2K problems, addressing foreseen $\mathrm{Y} 2 \mathrm{~K}$ events or responding to unforeseen $\mathrm{Y} 2 \mathrm{~K}$ events. The spectrum of human response and choices will occur and their reaction to real or anticipated Y2K events can make things worse.

Simultaneity - Y2K may not be a single event. Y2K failures could be multiple events with varying degrees of severity and duration. In addition, Y2K events could occur before and after January 1,2000 , and a single event could result in a chain reaction.

The Hanford Y $2 \mathrm{~K}$ Business Continuity Planning process is intended to assist the site in reducing Y2K risks by identifying measures to safeguard the ability of the Hanford site to maintain site operations if Y2K events should occur. While it does not offer a long-term solution to Y2K failures, it will help the site prepare for potential Y2K events and facilitate the restoration of normal operations at the earliest possible time and in the most cost-effective manner. 
The management and technical benefits of Business Continuity planning include:

- Provides DOE-RL management with a high-level overview of the Y2K business risks and solutions

- Ensures DOE-RL management ownership of business operations

- Ensures that Y2K efforts and resources are integrated into existing contingency, disaster recovery and emergency preparedness efforts

- Reduces the potential impact of $Y 2 \mathrm{~K}$ events on site operations

\subsection{ROLES AND RESPONSIBILITIES}

Table 1: Roles and Responsibilities

\begin{tabular}{|lllll|}
\hline Provide Leadership & $\begin{array}{l}\text { Develop business } \\
\text { continuity } \\
\text { guidelines and } \\
\text { schedules }\end{array}$ & Understand risks & $\begin{array}{l}\text { Identify internal } \\
\text { events }\end{array}$ \\
$\begin{array}{llll}\text { Understand Y2K } \\
\text { risks }\end{array}$ & $\begin{array}{l}\text { Identify external } \\
\text { events }\end{array}$ & $\begin{array}{l}\text { Identify emergency } \\
\text { safe site operations }\end{array}$ & $\begin{array}{l}\text { Identify business } \\
\text { impacts }\end{array}$ \\
Concur on plans & $\begin{array}{l}\text { Prepare Business } \\
\text { Continuity Plan }\end{array}$ & Concur on plans & $\begin{array}{l}\text { Prepare/Tests } \\
\text { Contingency Plan }\end{array}$ \\
$\begin{array}{l}\text { Participate in drills, } \\
\text { EOC }\end{array}$ & $\begin{array}{l}\text { Ensure IV \& V is } \\
\text { performed }\end{array}$ & $\begin{array}{l}\text { Provide direction to } \\
\text { contractors }\end{array}$ & $\begin{array}{l}\text { Prepare Y2K } \\
\text { Emergency } \\
\text { Management Plan }\end{array}$ \\
Provide resources & $\begin{array}{l}\text { Monitor, track \& } \\
\text { report status }\end{array}$ & Fund activities & $\begin{array}{l}\text { Form IT and } \\
\text { facilities SWAT } \\
\text { Teams }\end{array}$ \\
& $\begin{array}{l}\text { Share and prepare } \\
\text { corrective actions }\end{array}$ & & Implement plans \\
Communicate & Communicate & Communicate & Communicate \\
\hline
\end{tabular}

\subsection{HANFORD'S BUSINESS CONTINUITY PLANNING PROCESS}

The Hanford BCP Process can be described in four general phases:

(1) Planning - Identifying Y2K events that could have a negative consequence on the site's business and operations, and defining a set of appropriate management actions. (2)

Prevention - Assessing risks to the site, and taking actions that reduce the probability of a Y2K event occurrence (event mitigation) 


\section{Hanford Year 2000 Business Continuity Plan}

(3) Preparation - Preparing for the possibility that the Y2K event will occur and creating necessary contingencies. This includes establishing procedures, and conducting tests and drills.

Performance - Executing Y2K contingency and emergency preparedness plans.

\subsection{INPUT}

The input to this approach includes both the GAO Y2K business continuity and contingency planning guidelines, GAO/AIMD - 10.1.19 and the DOE-HQ Directives and Guidance dated January 28, 1999.

\subsection{KEY ACTIVITIES}

\subsubsection{Y2K Business Continuity Planning}

The risk of $\mathrm{Y} 2 \mathrm{~K}$ failures are not limited to internal computer systems but include potential failure of embedded microprocessors installed in buildings and process control systems. Hanford also depends on information and data from our business partners - including other federal agencies, state and local agencies. Finally, Hanford relies on external electrical power telecommunications and local security services. Y2K failure of our business partner or external service provider is also a risk that must be addressed.

Figure 1: Hanford Business Continuity Planning Process

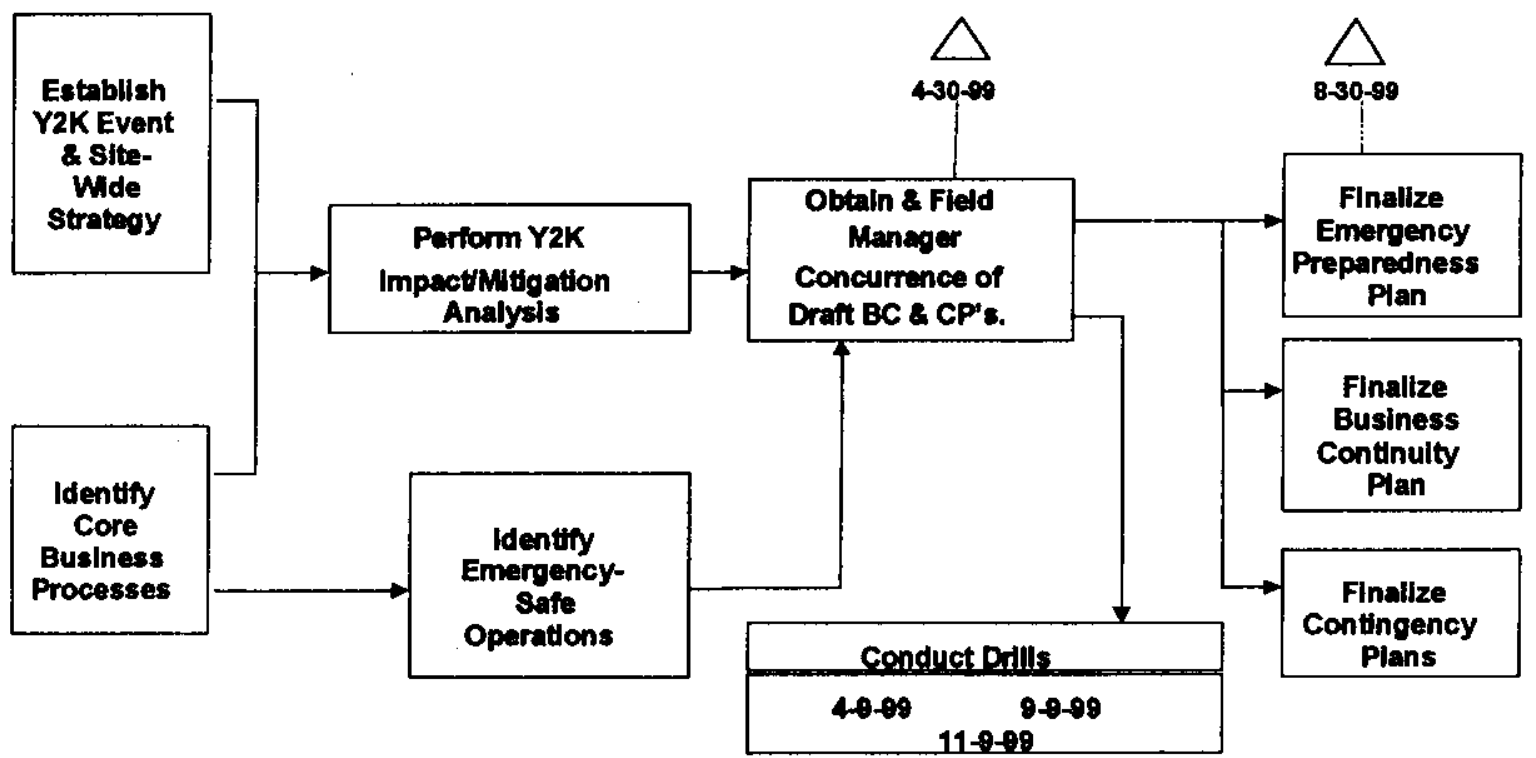

The key elements of Hanford's Y2K Business Continuity Planning are (1) establish the Y2K event and site wide strategy (2) identify core business processes (3) perform Y2K impact/mitigation analysis (4) identify emergency safe operations (5) obtain field managers concurrence of draft BCP and CPs (6) conduct tests and drills and (7) finalize BCP, CPs and EPP. 
DOE-RL, with support of the site contractors, will identify those systems and services that are required to maintain emergency-safe operation. Emergency-safe operations are those services and systems required by the site to protect the health of onsite and offsite personnel, to protect the environment and to provide adequate security.

\subsubsection{Y2K Contingency Planning}

The objective of contingency planning is to reduce potential impacts of Y2K events for systems and services necessary for emergency safe operations. DOE-RL will prepare contingency plans for each core business process and develop procedures for alternative solutions and/or compensatory actions to reduce the impact of $\mathrm{Y} 2 \mathrm{~K}$ events to acceptable levels. Contingency Plans may be produced for specific systems and/or facilities or projects. They may or may not include "Zero-Day" Transition Plans. It is not necessary to develop a separate contingency plan for each system/service identified as it may be appropriate to develop a single plan for a facility or a system that covers several operating locations.

Contingency plans will be tested to ensure that procedures can be implemented successfully if a Y $2 \mathrm{~K}$ event occurs and train the appropriate personnel to ensure personnel efficiency in the event the plans are activated. It is recommended that $\mathrm{Y} 2 \mathrm{~K}$ events and procedures that activate the Y2K Contingency Plan and events, and procedures that terminate Y2K Contingency Plans be considered.

\subsubsection{Execute Plans}

Contingency plan execution consists of the actions taken prior to a potential $\mathrm{Y} 2 \mathrm{~K}$ event (preemptive) and after the occurrence of a Y2K event (either post incident or reactive response). It includes monitoring of contingency triggers and implementation of contingency operations.

Preemptive Measures - Activities implemented prior to the occurrence of a Y2K event, i.e. verifying the $\mathrm{Y} 2 \mathrm{~K}$ readiness of essential service providers contracting for alternate services; stockpiling of critical supplies; staffing the Emergency Operation Center; shutting down systems and facilities and staging personnel on-site prior to the millennium change.

Post-Incident Actions - Activities implemented after the event, i.e. monitor events as it moves around the world; phased startup of facilities and equipment; implementation of manual operations and communications with major service providers.

Reactive Measures - Activities implemented when a Y2K event occurs i.e. activate business response teams to minimize spread and duration of problem; activate contingency and disaster recovery plans. Activate facility response team.

\subsubsection{Continue Operation}

This activity includes restoring/restarting systems and services as required and the notification of appropriate authorities of operational status or problem resolution. 


\section{Hanford Year 2000 Business Continuity Plan}

\subsubsection{Monitor and Report Progress / Awareness and Communications}

DOE-RL and the site contractors will monitor, track and report progress for the $\mathrm{Y} 2 \mathrm{~K}$ business continuity planning efforts. In addition, DOE-RL will institute an awareness and communications program including presentations; briefings, seminars and publications to ensure site personnel and local residents are fully aware of DOE's Y2K activities and contingency planing.

\subsection{OUTPUT}

The key output of this planning effort is illustrated in Figure 1.

Figure 2: Y2K Business Continuity

\section{II a}

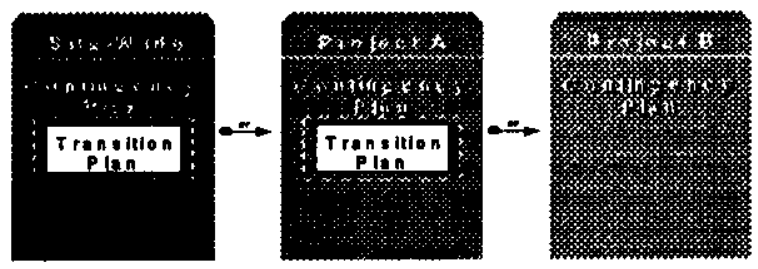

\section{Line}

Y2K Contingency Plans - An operational plan, which describes the steps a system owner plans to take to ensure that the functionality of a system is maintained in the event of an internal or external Y2K-related failure. See Attachment 2 for Contingency Plan Guidelines. This plan should not be confused with the DOE-HQ requirement to prepare a contingency plan for a system that fails to meet the validation milestone date of February 15, 1999.

Zero-Day Transition Plan - Identifies specific zero-day transition actions and procedures for the period between December 30, 1999 and January 4, 2000, and February 28, 2000, through March 1, 2000. If identifies roles and responsibilities, schedules and resources required.

Y2K Emergency Preparedness - Identifies the specific emergency response actions and procedures for a Y2K event(s). (It utilizes the Emergency Preparedness Plans and infrastructure currently in effect).

\subsection{Hanford's Y2K Event Description}

Based on information from several sources, such as Bonneville Power Administration (BPA), Washington State and other industries, the Hanford Y2K event falls into two categories, external and internal. External events are defined as the possible failure of offsite systems which, in some manner, interface or provide services or products to the Hanford Site. Examples of an external event include less of electrical power, disnuption of phone service, 
and loss of transportation. Internal events are defined as the possible failure of onsite systems, such as software applications, equipment items, or onsite telecommunications.

Following is a graph that identifies the probabilities and the approximate times when $\mathrm{Y} 2 \mathrm{~K}$ events are most likely to occur on the Hanford Site:

Figure 3: Y2K Risk Levels

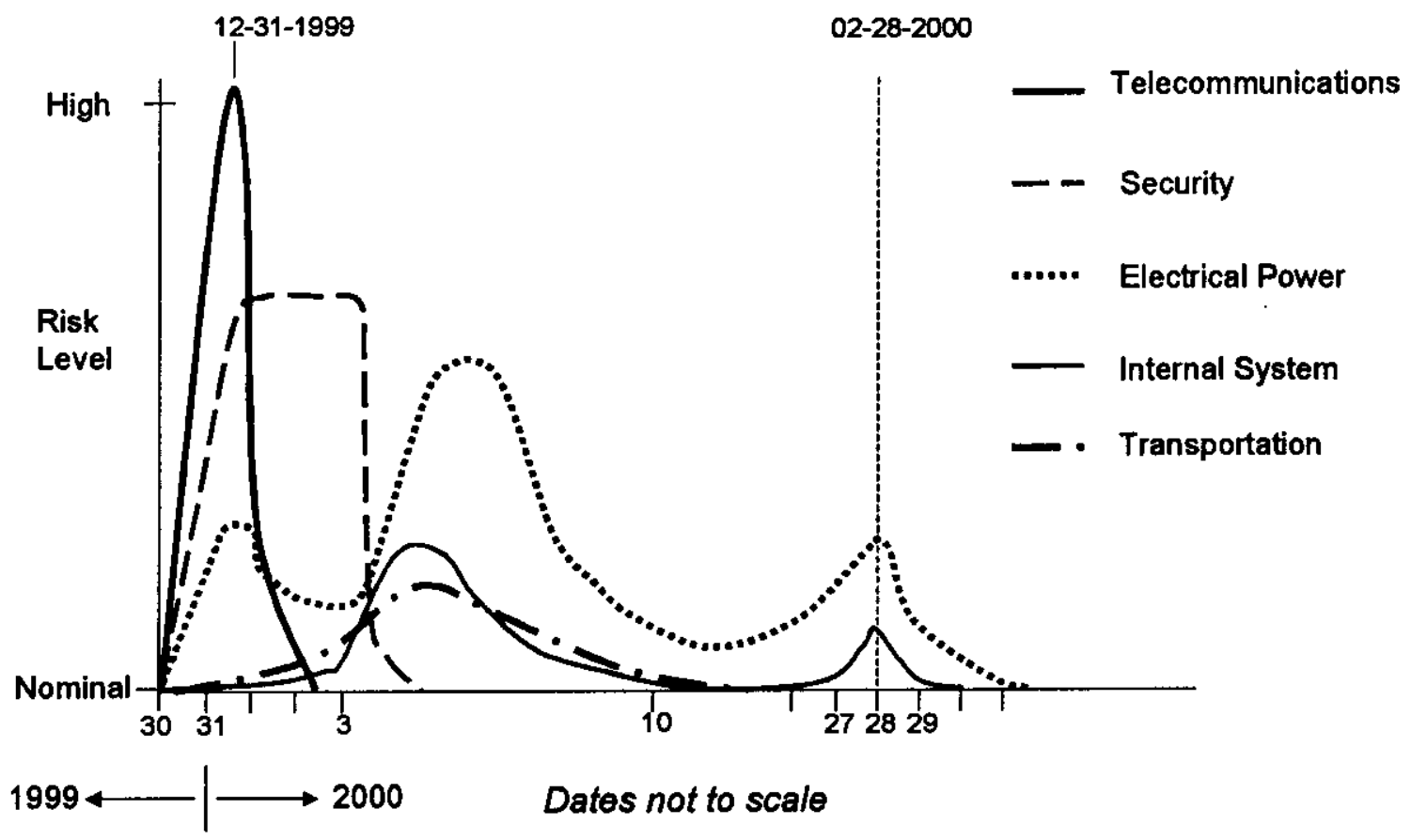

\subsubsection{Electrical Power}

Delivery of electrical power to the Hanford Site is divided into three segments: generation, transmission and distribution. Each of these segments is owned and operated by different entities and each may have a different Y2K-related risk.

Electric power generation for the Hanford Site is a combination of hydroelectric, thermo (coal, gas, etc.) and nuclear. This diversity of power generation is viewed as an advantage. The chance of having a simultaneous failure that would affect all generators is considered to be low. The Site is also fortunate that it has a 100-megawatt nuclear power plant feed connection at the same substation from which the Site acquires its power.

The transmission system that delivers electrical power to the Hanford Site is owned and operated by the BPA, and has been in existence since 1937. The Y2K risk to the transmission system is much less than the $\mathrm{Y} 2 \mathrm{~K}$ risk to the generation segment. The transmission system is comprised of wires and poles. The greatest Y2K risk involves the communication system that is used to 
control devices such as circuit breakers and switches. The use of voice communication and the staging of additional personnel in key locations, such as substations, could mitigate this risk.

The electric power distribution system on the Hanford Site is a combination of Hanford Site and BPA-owned and operated systems. The Y2K risk associated with the distribution system is similar to that of the transmission system. It is made up of basically the same components that comprise the transmission system. The onsite utility group works directly with BPA on a regular basis, and will continue to do so to ensure that communications are maintained during the $\mathrm{Y} 2 \mathrm{~K}$ rollover.

Another issue, which is associated with the reliability of the electrical power, involves the impact that the consumer may have on the power system. During a period starting on January 1,2000 , there is a possibility of intermittent power failures due to a major consumer of power dropping off the power system because of Year 2000 failures in their operations. This loss of a major electrical load could cause instabilities in the power grid, causing one or more of the power system components to shutdown.

The Y2K impact to the Hanford Site could be an intermittent/continuous disruption starting on January 1,2000 , and extending over a period of 60 days. Planning for this event should assume a 3-day minimum disruption both for operations that impact personnel health, safety, security and environmental impacts.

\subsubsection{Telecommunications}

Telecommunications is a key system on the Hanford Site functions, and the loss of these systems would cause a major disruption. The telecommunication system utilized is a combination of on-site and off-site components. The site, as it is configured, provides telephone service through a site-owned and operated telephone switch located in the 300 Area. This switch provides phone service to the majority of the site facilities, including leased facilities and the Federal Building. The phone switch also provides the ability to communicate off-site.

The components that make up the on-site and off-site telecommunication system are very similar in nature. The systems are mainly electronic switches and cables. The main component that is at risk involves the billing systems. Although the failure of the billing system would be an inconvenience, the main function of the switch would not be affected. Consequently, very few system reliability problems are expected to occur. However, on January 1,2000, there may be an unprecedented volume of calling (e.g., many times that of Mother's Day). The main problem may be a "busy signal," rather than any date-related problem. Because the high off-site call volume should not affect the on-site phone system, the internal telecommunication system should be at a low risk of failure.

The Hanford Site could be impacted by high call volume for a period of two days starting January 1, 2000 for offsite telecommunications. 


\subsubsection{Transportation}

Transportation involves the ability to obtain supplies and services to support daily operations. With the advent of "Just-In-Time" warehousing, many suppliers keep a limited supply of goods on hand. The ability to replenish goods quickly depends on all types of transportation. Supplies that could be affected may include delivery of food, fuel, and repair parts. As with supplies, a number of services may be affected by a disruption in transportation, such as emergency services. The risk associated with transportation is not easily defined.

Transportation is made up of several systems ranging from the computerized dispatching systems, to the physical vehicles, such as trucks and airplanes, all of which could be affected by a Y2K issue. For the Hanford Site, this impact could be a delay in services during the period January 1, 2000 to January 7, 2000.

\subsubsection{Security}

In recent years, local protection agencies have been enlisted to augment the Hanford Patrol. During the transition to the Year 2000, the Hanford Site may experience an increased risk of a security breach. Because of the time of year (winter and New Years Eve) the local protection agency may not be able to respond as quickly, or in large enough numbers, to avert a security event.

The Y2K event could impact the site's ability to maintain security and other law enforcement activities for a period from January 1, 2000, to January 3, 2000.

\subsubsection{Internal Systems}

194 PHMC Y2K projects were implemented and validated by July 31, 1999. Based on industry analysis, there is an expected five percent failure rate of the systems that have been renovated for Y2K. These failures may be due to injecting new errors while renovating program code for $\mathrm{Y} 2 \mathrm{~K}$ and for issues that were not identified during assessment. This equates to a possible Y2K failure of ten systems on the Hanford Site.

Table 2 summarizes the Hanford Y2K events description.

Table 2: Y2K Event Description Summary

\begin{tabular}{|c|c|c|c|}
\hline 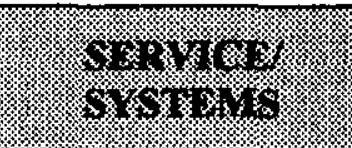 & 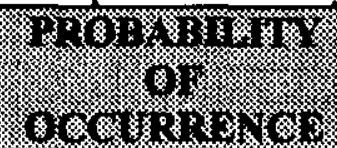 & 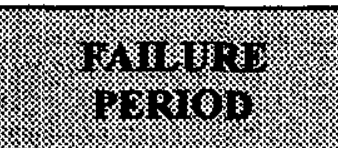 & 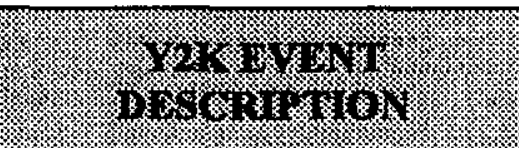 \\
\hline Telecommunication & High & $12-30-99$ to $1-2-20$ & $\begin{array}{l}\text { Intermittent interruptions } \\
\text { over } 2 \text { day period }\end{array}$ \\
\hline Security & Moderate & $12-30-99$ to $1-3-00$ & $\begin{array}{l}\text { Attempted breach of } \\
\text { security over } 3 \text { day period }\end{array}$ \\
\hline
\end{tabular}

April, 23, 1999 
Hanford Year 2000 Business Continuity Plan

Table 2: Y2K Event Description Summary Continued

\begin{tabular}{|l|l|l|l|l|}
\hline Electrical Power & Moderate & $12-30-99$ to 3-1-00 & $\begin{array}{l}\bullet \text { Intermittent } \\
\text { disruptions of up } \\
\text { to } 3 \text { days over a } 60 \\
\text { day period }\end{array}$ \\
\hline Transportation & Moderate & $12-30-99$ to 3-1-00 & $\begin{array}{l}\bullet \text { Delays of } 1-2 \text { days } \\
\text { over } 14 \text { day period }\end{array}$ \\
\hline Internal System & High & $1-2-00$ to $0-4-00$ & $\begin{array}{l}\text { 5\% of internal } \\
\text { systems will } \\
\text { experience Y2K } \\
\text { failures }\end{array}$ \\
\hline
\end{tabular}

\subsection{HANFORD'S BUSINESS CONTINUITY STRATEgY}

Hanford's Y2K Business Continuity planning strategy is illustrated in Figure 4, and is summarized as follows:

- Prior to December 31, 1999, the Site will initiate cost-effective, preemptive actions that will reduce the potential impact of $\mathrm{Y} 2 \mathrm{~K}$ events on site-operations.

- On December 29 and 30, 1999, the site will initiate a time-phased curtailment of site operations consistent with normal weekend operations and designated preemptive actions.

- On December 31,1999, the site will initiate either a time-phased curtailment or startup of site operations based upon real-time assessment of both external and internal Y2K events.

Figure: 4 Hanford Business Continuity Strategy

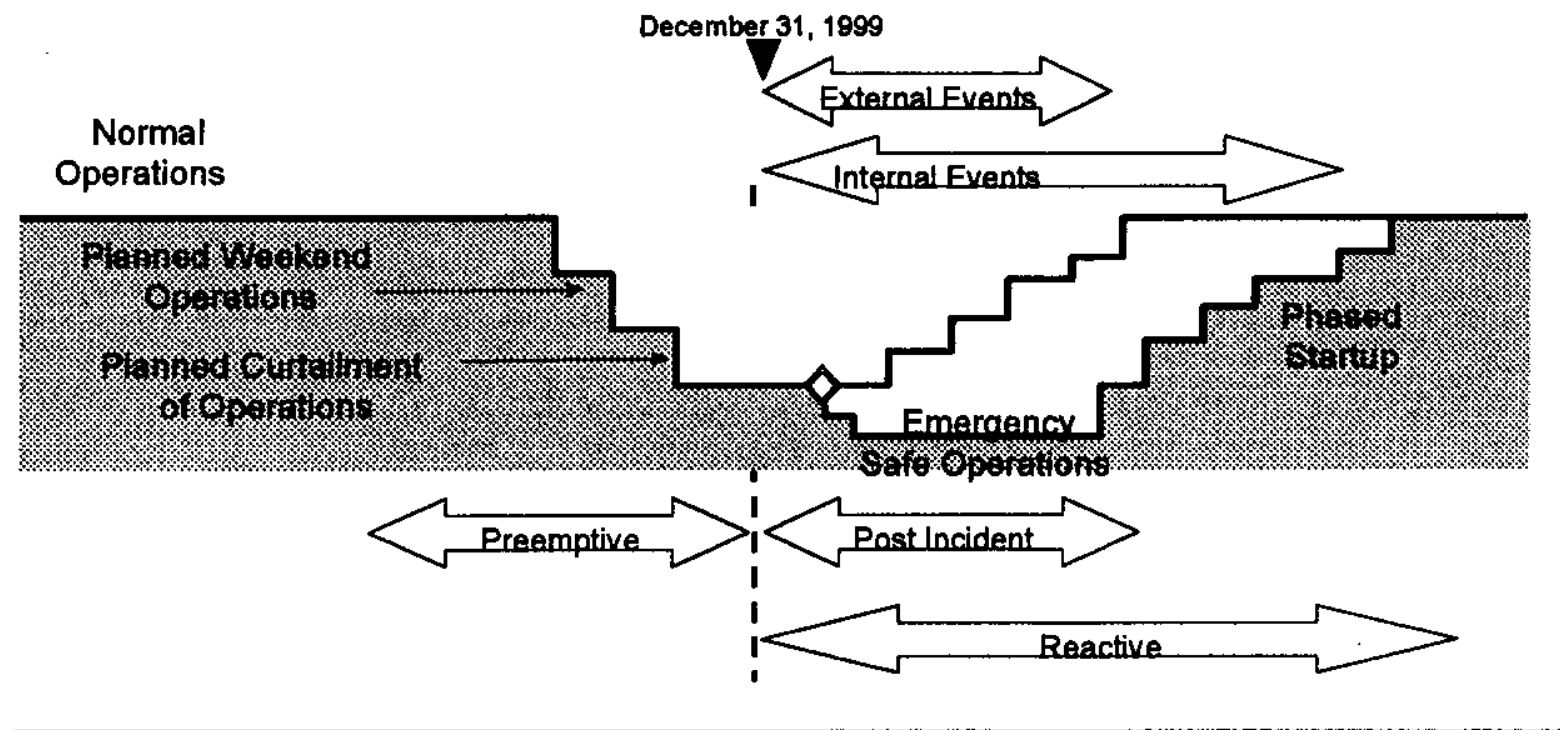

April, 23, 1999 


\section{Hanford Year 2000 Business Continuity Plan}

The actions that may be implemented are illustrated in Figure 4. This figure identifies December 31, 1999 as the baseline for determining if an action is defined as Preemptive, or Post Incident.

\subsubsection{Preemptive Actions}

Preemptive actions are steps to be taken prior to December 31, 1999 to minimize or mitigate Year 2000 impacts. The proper identification of preemptive activity will greatly reduce the need for post-incident actions. The following is a list of the major preemptive actions that will be implemented.

- Staff the Emergency Operations Center prior to the year 2000 transitions.

- Stage additional personnel at critical facilities.

- Reduce the operational levels of non-critical facilities.

- Stockpile critical supplies (generators, batteries, fuel etc.).

\subsubsection{Post Incident Actions}

Post Incident Actions are those actions that will be implemented based on identified triggers. Triggers are defined as events or predefine points of time when an action will be implemented. Examples of triggers could include the loss of electrical power or the failure of an automated system. Just as with the preemptive actions post incident actions may be implemented at a site-wide or at a facility level. The following is a list of Post Incident Actions that may be implemented to assure the safe operations of the site:

- The shutdown of a facility or system.

- The Implementation of a predefined contingency plan

- Operate utilizing a manual procedure

- Mobilize additional personnel

- Implement alternate means of communication

- Utilize backup power

- Activation of a Year 2000 "SWAT" team to repair a failed system.

The above lists identify actions that could be implemented due to events or failures. The specific facility actions will vary based on operational needs and the level of support that it must provide to the site. Site wide actions required should fall mainly into the preemptive category. As stated above, the preemptive active can greatly reduce the number of post incident actions that may need to be implemented. The BC strategy is a critical part of preparing for the Year 2000 transition.

\subsection{HANFORDS Y2K EVENT ASSUMPTIONS}

The following defines the Hanford Y2K event assumptions that describe the site wide services to be available/unavailable.

TABLE 3: Available Systems/Services

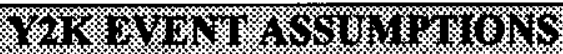


- Site-wide telephone, two-way radio, and telephone "85-paging" systems will be available.

- Fire notification systems (RAFAR) will be operational for $\mathbf{4 8}$ hours after the loss of electrical power.

- Emergency response personnel will be available (fire, patrol).

- Site emergency alarm systems will be operational (cash phones, siren).

- Site water system and sanitary sewer system will be operational (K Basin will have potable water only-NO firewater, $100 \mathrm{~N}$ will have firewater only-NO potable water).

- Natural gas to the site will be available.

- Emergency operations center (EOC) will be staffed from December 31, 1999 until event completion and will provide site-wide $\mathrm{Y} 2 \mathrm{~K}$ coordination and communication

- If an electrical power outage occurs, electrical power will be restored on priority basis.

- Diesel fuel can be stored in $200 \mathrm{~W}$ area if required

- Gasoline will be available throughout the event at $200 \mathrm{E}$ and 100 area stations.

- Any modifications to the fire protection/suppression systems (i.e.: draining of pipes, etc.) will be performed by the Hanford Fire Maintenance Department.

- Essential personnel will be assigned to shifts over the time period of concern.

- Assigned personnel are responsible for getting to and from work on their assigned shifts and providing they're own food.

Table 5: Unavailable Systems/Services

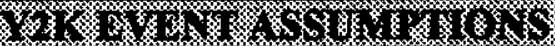

- Dosimeter readings will not be made during the period January 1, 2000 through January 7, 2000.

- Whole body counter will not be available during the time period of January 1,2000 through January 7, 2000.

- The PHMC central computing facility (BLDG 339A) will not be available from December 30, 1999 until reliable, stable electrical power is available (no sooner than January 2, 2000).

- JCI package boilers will NOT be available unless they have auxiliary power. 
2.7 HANFORDS CORE BUSINESS PROCESSES

Table 6: Core Business Processes

\begin{tabular}{|c|c|c|}
\hline 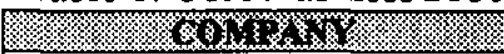 & 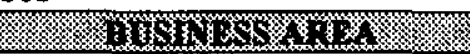 & 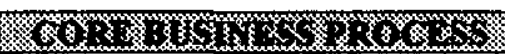 \\
\hline \multirow{5}{*}{ PHMC } & $\begin{array}{l}\text { PROJECTS AND } \\
\text { FACILITIES }\end{array}$ & $\begin{array}{ll}- & \text { BWHC-300 Area } \\
- & \text { BWHC-FFTF } \\
\text { - } & \text { BWHC-PFP } \\
- & \text { DESH-WNSFF/FASTER } \\
- & \text { LMHC-TWRS } \\
\text { WMH-Solid Waste } \\
\text { Operations } \\
\text { WMH-Liquid Effluent } \\
\text { Operations } \\
\text { WMH-Analytical Laboratory } \\
\text { Operations } \\
\text { WMH-Data Systems } \\
\end{array}$ \\
\hline & $\begin{array}{c}\text { SITE } \\
\text { COMMUNICATIONS }\end{array}$ & $\begin{array}{ll}- & \text { FDH Telephone System } \\
\text { - } & \text { FDH Two-way Radio } \\
\text { - FDH Site-paging } \\
\text { FDH Hanford Local Area } \\
\text { Network (HLAN) }\end{array}$ \\
\hline & SAFETY \& SECURITY & $\begin{array}{ll}- & \text { FDH Nuclear Safety } \\
- & \text { FDH Environmental } \\
& \text { Protection } \\
\text { - } & \text { FDH Radiation Protection } \\
\text { - } & \text { FDH Occupational Safety } \\
\text { - } & \text { FDH Fire Protection } \\
\text { - } & \text { FDH Security Protection } \\
& \text { Management Emergency } \\
\end{array}$ \\
\hline & $\begin{array}{l}\text { SITE UTILITIES } \\
\text { AND SERVICES }\end{array}$ & $\begin{array}{ll}- & \text { DYN Electrical Utilities } \\
\text { - } & \text { DYN Water Utilities } \\
\text { - } & \text { DYN Sewer Utillities } \\
\text { - } & \text { DYN Transportation } \\
\text { - Operations } \\
\text { - DYN Fleet maintenance } \\
\text { DYN Materials Management }\end{array}$ \\
\hline & BUSINESS MANAGEMENT & $\begin{array}{ll}- & \text { FDH Financial Management } \\
- & \text { FDH Production Services } \\
\end{array}$ \\
\hline PNNL & PNNL & $\begin{array}{ll}\text { - Facilities \& Operations } \\
\text { - Financial Processing System } \\
\text { Hanford Environmental } \\
\text { Dosimetry Program } \\
\text { - Human Resources } \\
\text { Information System } \\
\end{array}$ \\
\hline BHI & BHI & $\begin{array}{l}\text { - Business Application } \\
\text { - Ground Water }\end{array}$ \\
\hline HEHF & HEHF & $\begin{array}{l}\text { - Medical Surveillance } \\
\text { Program }\end{array}$ \\
\hline
\end{tabular}

April, 23, 1999 


\subsection{BUSINESS IMPACTS/MITIGATION APPROACHES}

Table 7: Business Impact/Mitigation Approach

\begin{tabular}{|c|c|c|}
\hline 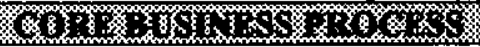 & W & 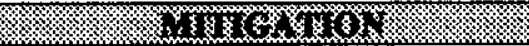 \\
\hline - BWHC-300 Area & $\begin{array}{l}\text { - Potential frozen pipes \& } \\
\text { facilities damage }\end{array}$ & $\begin{array}{l}\text { - Implement pipe draining } \\
\text { process }\end{array}$ \\
\hline - BWHC-FFTF & - Loss of plant HVAC/lights & $\begin{array}{l}\text { - Operate @ "Minimum-Safe" } \\
\text { condition (existing contingency } \\
\text { plans) }\end{array}$ \\
\hline - BWHC-PFP & $\begin{array}{l}\text { - Loss of plan HVAC/control } \\
\text { system }\end{array}$ & $\begin{array}{l}\text { - Operate @ Minimum-Safe" } \\
\text { condition (existing contingency } \\
\text { plans) }\end{array}$ \\
\hline - BWHC-WESF/FASTER & - Loss of plant HVAC & $\begin{array}{l}\text { - Operate @ "Minimum-Safe" } \\
\text { condition (existing contingency } \\
\text { plans) }\end{array}$ \\
\hline - DESH-SNF & $\begin{array}{l}\text { - Shutdown of facility and } \\
\text { construction operations }\end{array}$ & $\begin{array}{l}\text { Operate @ "Minimum-Safe" } \\
\text { condition (existing contingency } \\
\text { plans) implement manual } \\
\text { operations }\end{array}$ \\
\hline - LMHC-TWRS & $\begin{array}{l}\text { - Undefined until study } \\
\text { complete }\end{array}$ & - $\mathrm{TBD}$ \\
\hline $\begin{array}{l}\text { WMH-Solid Waste } \\
\text { Operations }\end{array}$ & - Facility Shutdown & $\begin{array}{l}\text { Implement existing facility \& } \\
\text { systems Contingency plans }\end{array}$ \\
\hline $\begin{array}{l}\text { WMH-Liquid Effluent } \\
\text { Operations }\end{array}$ & - Shut down of operations & $\begin{array}{ll} & \text { Shut down operations } \\
\text { - } & \text { Implement existing shutdown } \\
& \text { procedures } \\
\end{array}$ \\
\hline $\begin{array}{l}\text { WHM-Analytical } \\
\text { Laboratory OperationS }\end{array}$ & $\begin{array}{l}\text { - Facility shutdown } \\
\text { - }\end{array}$ & $\begin{array}{l}\text { Operate " @ "Minimum-Safe" } \\
\text { condition } \\
\text { - Shutdown data base }\end{array}$ \\
\hline - WMH-Data Systems & - Inability to provide reports & $\begin{array}{l}\text { - Prepare reports manually/delay } \\
\text { reporting }\end{array}$ \\
\hline
\end{tabular}

Table 8: Safety and Security

\begin{tabular}{|c|c|c|}
\hline Wh n & 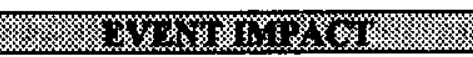 & 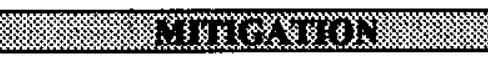 \\
\hline $\begin{array}{l}\text { FDH-Environmental } \\
\text { Protection }\end{array}$ & - Inability to provide reports & - Perform manual operations \\
\hline - FDH-Radiation Protection & $\begin{array}{l}\text { - Inability to establish access } \\
\text { eligibility }\end{array}$ & $\begin{array}{l}\text { Provide qualification records } \\
\text { prior to event }\end{array}$ \\
\hline - FDH-Occupational Safety & $\begin{array}{l}\text { - Inability to provide OSHA } \\
\text { reports }\end{array}$ & - Manually prepare forms \\
\hline - FDH-Nuclear Safety & - Inability to provide reports & $\begin{array}{l}\text { - Perform manual report } \\
\text { preparation }\end{array}$ \\
\hline
\end{tabular}


Hanford Year 2000 Business Continuity Plan

Table 9: Site Communication

\begin{tabular}{|c|c|c|}
\hline 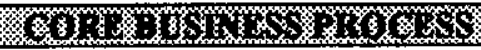 & 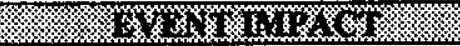 & Hor \\
\hline - FDH-Telephone System & $\begin{array}{l}\text { Loss of telephone service } \\
\text { after hours }\end{array}$ & $\begin{array}{l}\text { - Install portable generators/ } \\
\text { provide technical support }\end{array}$ \\
\hline - FDH-Two-way Radio & $\begin{array}{l}\text { - Degradation of } \\
\text { communications after xx } \\
\text { hours. }\end{array}$ & $\begin{array}{l}\text { - Install portable generators at } \\
\text { selected sites }\end{array}$ \\
\hline - FDH-Site Paging & $\begin{array}{l}\text { Loss of paging service after } \\
\text { hours. }\end{array}$ & - Upgrade telephone system \\
\hline $\begin{array}{l}\text { FDH-Hanford Local Area } \\
\text { Network (HLAN) }\end{array}$ & $\begin{array}{l}\text { - Loss of service/damage to } \\
\text { equipment }\end{array}$ & $\begin{array}{l}\text { - Install electrical surge } \\
\text { protection devices }\end{array}$ \\
\hline
\end{tabular}

Table 10: Site Utilities and Services

\begin{tabular}{|c|c|c|}
\hline 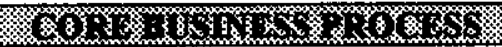 & 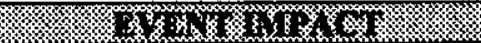 & 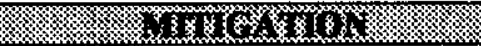 \\
\hline DYN-Electrical Utilities & - Loss of substation power & $\begin{array}{l}\text { - Install portable generators, } \\
\text { heaters \& two-way radios }\end{array}$ \\
\hline - DYN-Water Utilities & $\begin{array}{l}\text { Extended operation of } \\
\text { backup electrical generators } \\
\text { - Potential pipe freezing }\end{array}$ & $\begin{array}{l}\text { - Ensure adequate manpower } \\
\text { to support operations } \\
\text { - Implement freeze protection } \\
\text { plan } \\
\end{array}$ \\
\hline - DYN-Sanitary Services & $\begin{array}{l}\text { - Extended operation of sewer } \\
\text { lift stations }\end{array}$ & $\begin{array}{l}\text { - Ensure adequate manpower } \\
\text { to support operations }\end{array}$ \\
\hline $\begin{array}{l}\text { DYN-Transportation } \\
\text { Operations }\end{array}$ & $\begin{array}{l}\text { - Inability to start vehicles } \\
\text { (cold temp) }\end{array}$ & - Install portable generators \\
\hline - DYN-Fleet Maintenance & $\begin{array}{l}\text { - Inability to provide vehicle } \\
\text { fuel } \\
\text { - Inability to provide } \\
\text { maintenance support }\end{array}$ & - Install portable generators \\
\hline - DYN-Materials Management & $\begin{array}{l}\text { - Unable to provide logistic } \\
\text { support }\end{array}$ & $\begin{array}{l}\text { - Curtail operations to } \\
\text { essential personnel only }\end{array}$ \\
\hline - FDH-Production Services & $\begin{array}{l}\text { Damage to computer } \\
\text { equipment } \\
\text { - Facility damage } \\
\text { (cold weather) }\end{array}$ & $\begin{array}{l}\text { Curtail operations during } \\
\text { high risk periods } \\
\text { Drain pipes if necessary } \\
\text { (cold temp) }\end{array}$ \\
\hline
\end{tabular}

Table 11: Business Management

\begin{tabular}{|l|l|l|}
\hline FDH-Financial Management & $\bullet \begin{array}{l}\text { Delay of payroll and } \\
\text { accounts payable }\end{array}$ & $\bullet$ Perform manual operations \\
\hline
\end{tabular}


Hanford Year 2000 Business Continuity Plan

Table 12: PNNL

\begin{tabular}{|c|c|c|}
\hline 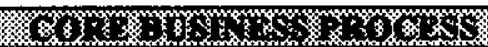 & W $13 \%$ & 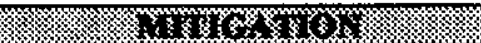 \\
\hline - Facilities \& Operations & $\cdot \mathrm{TBD}$ & - TBD \\
\hline $\begin{array}{l}\text { - Financial \& processing } \\
\text { System }\end{array}$ & $\begin{array}{l}\text { System unavailability } \\
\text { - Inability to send or receive } \\
\text { files }\end{array}$ & - Manually create entries \\
\hline $\begin{array}{l}\text { - Hanford Environmental } \\
\text { Dosimetry Program }\end{array}$ & - Loss of business function & $\begin{array}{l}\text { - Perform manual calculations } \\
\text { - Utilize backup services }\end{array}$ \\
\hline $\begin{array}{l}\text { Human Resources } \\
\text { Information System }\end{array}$ & - System unavailable & $\begin{array}{l}\text { Early preparation of payroll } \\
\text { checks }\end{array}$ \\
\hline
\end{tabular}

Table13: BHI

\begin{tabular}{|l|l|l|l|}
\hline & $\bullet$ Disruption of operations & $\begin{array}{l}\text { Pre-execute financial } \\
\text { transactions }\end{array}$ \\
\hline$\bullet$ Ground Water & $\bullet$ Freezing of pump hose pipes & $\bullet$ Install heaters \\
\hline
\end{tabular}

Table 14: HEHF

\begin{tabular}{|l|l|l|l|l}
\hline- Medical Surveillance & $\begin{array}{l}\text { Inability to perform business } \\
\text { functions }\end{array}$ & $\begin{array}{l}\text { Curtail operations to } \\
\text { essential personnel only }\end{array}$ \\
\hline
\end{tabular}

\subsection{DRULLS}

The following table identifies the Y2K drills to be performed.

Table 15: Y2K Business Continuity Drills

\begin{tabular}{|l|l|l}
\hline $4-9-99$ & Validate alternative communication process and train personnel \\
$9-9-99$ & $\begin{array}{l}\text { Validate PHMC Y2K readiness through simulations of loss of electricity and } \\
\text { Y2K date failures (tabletop exercises of select systems. }\end{array}$ \\
$11-18-99$ & Validate PHMC's EOC readiness through simulation of Y2K event.
\end{tabular}

\section{April 9, 1999 Drill}

The purpose of this exercise was to train and familiarize onsite and offsite electrical utility personnel with alternate communication processes. The Site Emergency Response Organization participated by exercising communication links with department of Energy Headquarters 
Emergency Operation Center (EOC). The exercise validated actions to be taken for events associated with $\mathrm{Y} 2 \mathrm{~K}$ related infrastructure and supporting system failures. In addition, this drill served as the basis for identifying modifications required in current strategies and contingency planning for $\mathrm{Y} 2 \mathrm{~K}$ related events. . The scenario was based upon credible events identified during $\mathrm{Y} 2 \mathrm{~K}$ readiness assessments. The scope of the exercise participation was limited to the EOC, Bonneville Power Administration (BPA) and site electrical utility personnel.

During the observation of the exercise the following opportunities for improvement were identified:

- The need to extend the range of the VHF radio provided to BPA

- Provide written formal procedure on the operation of the VHF radio provided to BPA

\section{September 9, 1999 Drill}

The purpose of this tabletop drill was to train and familiarize participants with the monitoring and progress reporting process and associated responsibilities that will be used during the rollover to the year 2000 at the Hanford Site. Drill participants included the Site Emergency Response Organization, DOE-RL, and key individuals from each of the Site major contractors. The drill was arranged as a tabletop to provide an opportunity for key process individuals to meet collectively, become familiar with their roles and responsibilities discuss and discern the process and provide feedback for revisions and enhancements. In addition, the drill served as a basis for identifying modifications required to the reporting process, current strategies and contingency planning for $\mathrm{Y} 2 \mathrm{~K}$ related events. The tabletop drill involved two scenarios. The first scenario assumed that no problems, Y2K related or otherwise, were encountered. The second scenario introduced weather and system problems.

During the Observation of the exercise the following opportunities for improvement were identified:

- Investigate the common failure points of the selected zero-day communication methods and determine whether the prioritization method is still appropriate.

- Develop a separate process for monitoring and reporting classified system status.

- Determine information security considerations that should be incorporated into the monitoring and reporting process.

- Require all rollover points of contact to carry an 85-pager. Incorporate those pager numbers into the contact list.

- Develop a Y2K tip sheet for those involved in the zero-day process that includes considerations and reminders as year 2000 approaches (e.g., charged/fresh pager batteries, ISDN phones will not work if power is out - only 'standard' handsets will work), publish list of essential IT personnel and backups, etc.) 
- Prepare several General Delivery messages during December with items that the general Hanford populace should be aware of (e.g., overview of rollover process, turn off PCs, reduce power consumption, etc.)

- Determine the work schedule for the Y2K Event Coordination Team during the rollover timeframe.

- Develop what criteria will terminate the Y2K Event Coordination Team prior to January 3, 1999.

- Ascertain what alternate communications and prioritization processes DOE HQ is using.

- Determine senior management expectations for reporting Y2K status.

- Determine the need for clearances to handle classified system status for those that will be at the Hanford Emergency Operations Center during the rollover.

\section{September 9, 1999 Drill}

The purpose of this drill is to exercise the Emergency Operations Center Staff and Y2K Participants. For this drill, a scenario will be prepared to simulate a December 31, 1999 cold weather blast hitting the site along with Y2K rollover. The weather driven event will cause numerous site related infrastructure events that will cause the EOC to make Safety decisions.

\subsection{SCHEDULES/MILESTONES AND COST ESTIMATES}

\subsection{SCHEDULE/MILESTONES}

Table 16: Schedule/Milestones

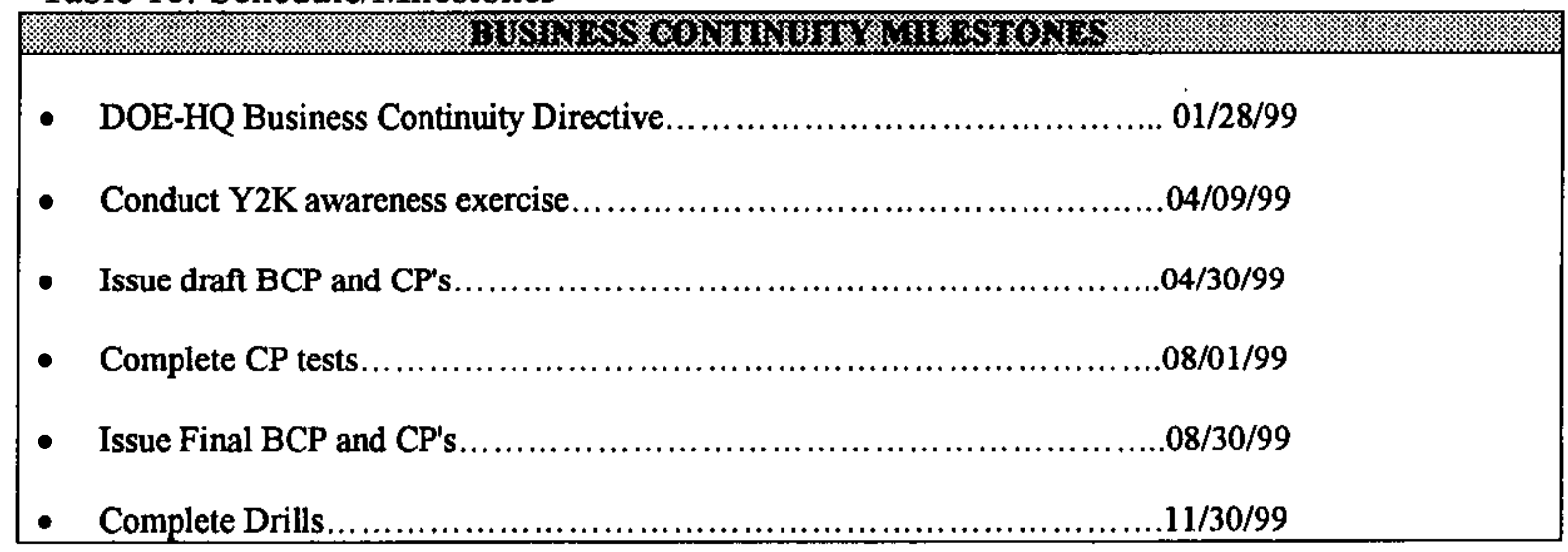




\subsection{Cost Estimate}

The estimate cost to support the business continuity effort is $\$ 490,000$ and $\$ 338,000$ for FY 1999 and FY 2000. The major cost drivers are three fold:

1. Upgrade Telephone, Two-Way Radio and "85-Pager system"- this activity includes the procurement and installation of backup electrical power generators. ( $\$ 285 \mathrm{~K})$

2. Upgrade TWRS Facility - this activity includes the engineering, procurement and installation of backup electrical generators for two TWRS facilities. (\$150K)

3. Modify TWRS Procedure - this activity is intended to identify and modify TWRS operating procedures to accommodate the $\mathrm{Y} 2 \mathrm{~K}$ planning event $(\$ 160 \mathrm{~K})$

Table 17: Cost Estimate

\begin{tabular}{|c|c|c|c|c|}
\hline & BWHC & $10 \mathrm{~K}$ & $10 \mathrm{~K}$ & $20 \mathrm{~K}$ \\
& WMH & $20 \mathrm{~K}$ & $10 \mathrm{~K}$ & $30 \mathrm{~K}$ \\
& LMH & $270 \mathrm{~K}$ & $130 \mathrm{~K}$ & $400 \mathrm{~K}$ \\
& DYN & - & $65 \mathrm{~K}$ & $65 \mathrm{~K}$ \\
& DESH & $5 \mathrm{~K}$ & $25 \mathrm{~K}$ & $30 \mathrm{~K}$ \\
& FDH & $185 \mathrm{~K}$ & $98 \mathrm{~K}$ & $285 \mathrm{~K}$ \\
& & & & \\
\hline PHML & TBD & TBD & TBD & TBD \\
\hline BHI & TBD & TBD & TBD & TBD \\
\hline
\end{tabular}




\section{ATTACHMENT 1: TERMS AND DEFINITIONS}

Y2K Business \& Operations Continuity - The process of maintaining emergency-safe site operations after the occurrence of foreseen or unforeseen $\mathrm{Y} 2 \mathrm{~K}$ events.

Y2K Business \& Operations Continuity Planning - The process of identifying Y2K risks, assessing the impact on site operations and the development and implementation of risk reduction strategies including site-wide project-specific Y2K Contingency Planning, "ZeroDay" Transition Planning and Emergency Response.

Emergency-Safe Site Operations - Those systems and services required by the site to protect the health of onsite and offsite personnel, to protect the environment and to provide adequate security.

"Graded" Business Continuity Approach - Establishes extent of business continuity activities commensurate with identified $\mathrm{Y} 2 \mathrm{~K}$ risks. That is, a high $\mathrm{Y} 2 \mathrm{~K}$ risk would result in extensive contingency planning activities; whereas, a low Y2K risk would result in minimum contingency planning activities.

Systems - Y2K mission essential and other than-mission critical systems.

Services - Products and services used to support Y2K mission essential and other than mission essential systems.

Service Provider - Any company, federal or state agency that provides goods or services to the site.

Y2K Event - A Year 2000 induced failure that has an impact on a system or service (i.e., computer shutdown, loss of transmission)

External - From outside site (e.g., from DOE-HQ, from other sites, from other companies/subcontractors)

Internal - From inside site (e.g., people assigned at the site, local DOE, etc.)

Y2K Contingency Planning - The process of identifying alternate solutions and compensatory actions taken to counteract unacceptable foreseen and unforeseen Y2K events. (Includes Disaster Recovery Planning)

"Zero-Day" Transition Planning - The development of site-wide actions and procedures to be implemented on key Year 2000 dates to address foreseen Y2K problems and to respond expeditiously to unforeseen Y2K events. For example, from September 30, 1999 to October 1, 1999, December 30, 1999 through January 1, 2000; and February 28, 2000 through March 1,2000 .

Emergency Preparedness - Identifies the specific emergency response actions and procedures for a Y2K event(s). (It utilizes, as much as practical, the Emergency Preparedness Plans and infrastructure currently in effect at each DOE site.) 


\section{Hanford Year 2000 Business Continuity Plan}

Y2K "Readiness" Monitoring and Reporting - The process of monitoring, tracking and reporting progress of the DOE sites in performing Y2K Business Continuity Planning and Implementation activities.

Year 2000 Compliance - Year 2000 Compliance means that a system or application is either fully compliant or $Y 2 K$ ready.

Note: The industry generally refers to this definition as $\mathrm{Y} 2 \mathrm{~K}$ readiness.

Fully Compliant - Fully compliant means the operation, performance and functionality of a system is not affected by dates prior to, during and after the year 2000 . This includes all existing data interfaces/exchanges to or from the system. In particular, the following rules are satisfied:

Rule 1- General Integrity - No value for current date will cause any - Date-based functionality must behave consistently interruption in operation.

Rule 2 - Date Integrity prior to, during and after the year 2000.

Rule 3 - Century Integrity - In all interfaces and data storage, the century in all dates must be specified either explicitly or by unambiguous algorithms or inference rules.

Rule 4 - Leap Year Integrity - Year 2000 must be recognized as a leap year. Note: Industry refers to "fully compliant" as simply "compliant".

Y2K Ready - Y2K Ready means that, although a system or application is not fully compliant, it has been determined to be suitable for continued use into the year 2000 . Solutions such as rolling back the system clock, use-as-is, retirement, manual work-arounds are examples of being $\mathrm{Y} 2 \mathrm{~K}$ ready. 


\section{ATTACHMENT 2: Y2K CONTINGENCY PLAN GUIDELINES}

This document describes a proposed format and content of a $\mathrm{Y} 2 \mathrm{~K}$ contingency plan. The plan should address the following items.

- Objective

- Plan Duration

- Criteria/Triggers

- Roles, Responsibilities, Authorities

- Plan Testing

- Operating in Contingency Mode

- Resource Plan

\section{OBJECTIVE}

The specific objectives of the plan must be clearly identified (e.g., continue in a degraded mode or abort the business function as quickly and as safely possible). If the Y2K contingency plan is for, foreseen $\mathrm{Y} 2 \mathrm{~K}$ event state the impact, desired work-around or operational level and remaining functionality. Separate any roles, procedures, responsibilities and actions for foreseen versus unforeseen $\mathrm{Y} 2 \mathrm{~K}$ events.

\section{CrITERIA/Triggers}

Identify trigger points or criteria for when the contingency plan will be implemented. The triggers or criteria may equate to a level or event.

\section{Plan Duration}

Identify the implementation and termination (if applicable) dates of the plan The expected duration could be as short as a few hours for cases with relatively quick fixes; however, it may be indefinite. Identify what events, activities or results would terminate the plan.

A Y $2 \mathrm{~K}$ contingency plan may be established as a standard operating procedure or it may have a specified life span that is based on the occurrence of certain criteria. The contingency plan will specify how the plan will or maintained throughout the life of the system or terminated.

\section{ROLES, RESPONSIBILITIES AND AUTHORITIES}

Define management, technical, operations, and the Year 2000 Project Office personnel roles and responsibilities for executing the provisions of the plan. An organization chart with assigned authority is useful. Identify the process for emergency notification of all impacted personnel, which should include site management and the Year 2000 Project Office. 


\section{Plan Testing}

Identify how the plan will be tested to ensure actual Y2K events can be handled as identified in the contingency mode procedures. The items to be considered for testing include:

- Approach

- Objectives

- Expected outcomes

- Roles and responsibilities

- Testing team, equipment, other resources

- Training requirements

- Schedule

- Test location

- Exit criteria

The testing should validate the functionality of the contingency procedures. Examine results for accuracy and consistency and note discrepancies. Ensure that:

- there is adequate capability to manage, record and track the contingency transactions through the alternate business process

- manual activities (in particular) and the alternative business process (in general) meet an acceptable performance

- an acceptable level of quality control is provided to critical parts of the alternate business process, and an acceptable level of integrity and consistency is provided to alternate databases

- contingency database requirements are defined for alternate implementation modes, and contingency bridges can provide conversion from the contingency environment back to the normal production environment

- any functional differences between the normal business process and the alternative business process can be reconciled or adjusted at the database level.

\section{OPERATING IN CONTINGENCY MODE}

\section{Criteria for Invoking a Contingency Mode}

Address the criteria that activates the plan (e.g., reaching the Y2K event date, experiencing serious system failures, incorrect dates, etc.). In other words, what events or dates indicate that a contingency mode of operation must be put in place? This criterion is referred to as a trigger and is included in the $\mathrm{Y} 2 \mathrm{~K}$ project schedule once the contingency plan is approved.

\section{Procedures for Invoking Contingency Mode}

Describe the procedures for initiating the $\mathrm{Y} 2 \mathrm{~K}$ contingency plan. If the plan covers a range of Y2K contingencies, it identifies the procedures used for implementing each of the various conditions (i.e. recovery from loss of data files, loss of a major component of hardware, 
transfer to an alternate processing location, etc.)

\section{Procedure for Operating in Contingency Mode}

Provide specific operating procedures for all Y2K events and triggers. Consideration should be given the three basic operating modes:

- Manual - Required when the system or equipment is completely inoperable and all processes have to be done manually (e.g., manual readings, calculations, file/data transfers, reports, etc.) to maintain minimal functionality.

- Semi-Automated - The use of Y2K compliant hardware and software tools and personnel to maintain system functionality.

\section{Criteria for Returning to Normal Operating Mode}

Establish the criteria that indicates a system/service can be restored to normal operation. In some instances, the original system will never be used again and the contingency plan should identify the procedures that deactivate or replace the original system.

\section{Procedure for returning to normal operating mode}

Describe the procedures to restore or restart the system/service. The procedure should include procedures to correct and restore corrupt/loss data and should identify system testing and $\mathrm{Y} 2 \mathrm{~K}$ certification as appropriate.

\section{Resource Plan for Operating in Contingency Mode}

Address all of the necessary resources (e.g. staff, materials, supplies, temporary hardware and software, facilities, etc.) required to successfully operates in the contingency mode. Additionally, the resource plan should include an estimated schedule.

\section{Training requirements for operating in contingency mode}

Identify essential training requirements to ensure that personnel are capable of successfully implementing the contingency operations.

\section{Contingency Mode Closeout}

Describe the activities and procedures to close out the contingency operation such as the problem, problem resolution, and date of resolution, and notification requirements (e.g., management, Year 2000 Project Office). 


\section{ATTACHMENT 3: ASSURANCE OF MISSION-CRITICAL SYSTEM CONTINGENCY PLAN COMPLETION}

System Name: System Owner:

The system Owner has documented completion of the following:

Date final mission-critical system Contingency Plan was completed.

Based on the information and documentation presented, the undersigned acknowledges that a Contingency Plan has been prepared, tested and has addressed all Y2K - related risks and provides for the continuity of operations for the function performed by the mission-critical system. Each mission-critical system should have this form completed.

$\overline{\text { Contractor Representative }} \quad \overline{\text { Date }}$

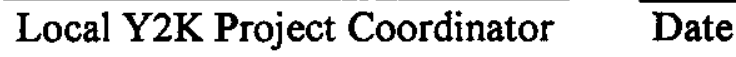

$\overline{\text { HQ/Field Office or Site Manager }} \overline{\text { Date }}$

Please retain this form for your files, and provide a copy, along with the completed missioncritical system Contingency Plan and other supporting documentation, to the Site Manager. Copies of Attachment 3 should be forwarded to the DOE Chief Information Officer (MA-4). Documentation should be made available to the appropriate Program Secretarial Officer(s) (PSO) and to the Office of the Chief Information Officer, if requested.

Direction for Business Continuity and Mission-Critical Contingency Planning, Revision 9 REVISED DRAFT: December 22, 1998. 